\section{SZABÓ Ildikó}

Neumann János Egyetem

Pedagógusképzó Kar

Mưvészeti és Anyanyelvi Nevelési Tanszék

ORCID: 0000-0003-2394-5237

\section{SZINGER Veronika}

Neumann János Egyetem

Pedagógusképző Kar

Múvészeti és Anyanyelvi Nevelési Tanszék

ORCID: 0000-0003-1334-4884

szinger.veronika@pk.uni-neumann.hu
Nemek és igenek

A fiúk olvasási motivációja és teljesítménye a kutatási eredmények és jó gyakorlatok tükrében ${ }^{1}$

Hazai és nemzetközi kutatások egyaránt arról számolnak be, hogy a fiúk átlagosan kevesebb időt töltenek olvasással, alacsonyabb olvasási motivációval rendelkeznek, kevésbé értékelik az olvasást, önmagukat kevésbé jó olvasónak tartják, mint a lányok, az olvasás inkább „lányos” időtöltésnek számít. A lányok és fiúk közötti különbség az életkorral csak nő, amit a PIRLS- és PISA-vizsgálatok eredményei is alátámasztanak. Az olvasás területén a nemek közötti különbség biológiai megközelítése azokat a veleszületett vagy az érés következtében a hormonális változásokkal párhuzamosan kialakuló tényezóket hangsúlyozza, amelyek a kognitív képességeket befolyásolják. A szociolingvisztikai szempontok pedig elsősorban azokat a különbségeket említik, amelyek a szocializáció során esetlegesen más mintákat közvetítenek az apa és az anya részéröl. A tanulmány bemutat néhány olyan pedagógiai aspektust is, amely az óvodában és iskolában segíti vagy sajnálatos módon hátráltatja a fiúk olvasóvá válását, az olvasói önkép, az olvasási teljesítmény vagy iskolai elōrehaladás alakulását. A tanulmány fö célja olyan jó gyakorlatok ismertetése, amelyek elsősorban a fiúkat célozzák meg. Az Olvasó apukák az óvodában elnevezésü finn projekt abból indul ki, hogy a fiúk érdeklődését az olvasás iránt leginkább egy férfi ideál, egy számukra szerepmodellként szolgáló felnőtt férfi keltheti fel. A Fiúk és könyvek (Boys \& Books) weboldal fóként azokhoz a felnöttekhez szól, akik a fiúk olvasóvá nevelésében bármilyen szerepet betölthetnek. A site fiús olvasnivalókat, az olvasástanításhoz módszertani ajánlásokat kínál. A Futball találkozása a kultúrával elnevezésü, kifejezetten a hátrányos helyzetű fiúk megszólítására alapozó német projekt arra a meggyőződésre épül, hogy a futball, a tanulás és a kultúra összekapcsolása sok gyereket motivál, és így elfogadóbbá, érdeklődőbbé válnak a tanulás és az olvasás iránt. „Az igazi férfiak”: egy amerikai jó gyakorlat fö tanulsága, hogy ha figyelembe vesszük, miről szeretnének olvasni, hallani, beszélgetni a fiúk, akkor a számukra vonzó szövegekben el tudnak mélyülni. A PISA-vizsgálatok egyértelmüen megmutatják, hogy ha elkötelezett olvasóvá válnak a fiúk, jobb teljesítményre képesek, mint a lányok. A tanulmányban felvázolt jó gyakorlatok ezen cél eléréséhez járulnak hoz$z a ́$.

Kulcsszavak: nemi különbségek az olvasásban, jó gyakorlatok, olvasási motiváció

\footnotetext{
${ }^{1}$ A tanulmány a Múzeumi és könyvtári fejlesztések mindenkinek című, EFOP-3.3.3-VEKOP-16-2016. azonosítószámú pályázati konstrukció keretében megvalósuló, „Az én könyvtáram” című kiemelt projekt keretében készült.
} 


\section{Bevezetés}

Képzeljünk el egy fiúgyermeket, aki olvasásszerető, könyvbarát családba születik. Otthon hatalmas családi könyvtár veszi körül, nagyon korán lesz baba-, majd kölyökolvasójegye, a könyvtár szinte születésétől ismerős, biztonságos közeg, aminek látogatását jutalomként éli meg. Az idősebb családtagok mindennap olvasnak, mesélnek neki. Akár nyugodtak is lehetnének a szülők, hiszen fiuk olyan útravalót kap kisgyermekkorában, amely talán egész életében elkíséri. Csakhogy ennek a fiúgyermeknek is kétesélyes az olvasóvá válása, ha arra gondolunk, hogy a fiúk kisebb-nagyobb mértékben minden országban hátrányban vannak a lányokkal szemben az olvasás, szövegértés tekintetében (Ábrahám 2006). A hazai és nemzetközi kutatások egyaránt arról számolnak be, hogy a fiúk átlagosan kevesebb időt töltenek olvasással, alacsonyabb olvasási motivációval rendelkeznek, kevésbé értékelik az olvasást, önmagukat kevésbé jó olvasónak tartják, mint a lányok, az olvasás inkább „lányos” időtöltésnek számít. A lányok és fiúk közötti különbség az életkorral csak nő. Az alsó tagozaton még a fiúk is jól teljesítenek, bár ha megnézzük a PIRLS-vizsgálatokat, amelyeket negyedikes diákok körében végeznek, ott is van különbség a lányok javára. A 2016-os mérés során a magyar lány tanulók átlagosan 13 ponttal jobb eredményt értek el, mint a fiúk (Lannert-Kaderják-Németh 2019). Ez a jelenség jellemző volt a korábbi mérésekre is. Ez a különbség a nemek között hazánkban egyébként kisebb, mint a nemzetközi átlag. Csakhogy a serdülőkor évei alatt, a felső tagozaton és középiskolában a fiúk általában lemaradnak a lányokhoz képest. A fiúk kevésbé kompetens olvasók, mint a lányok - és ez minden országra vonatkozik, ahol PISA-vizsgálatot végeztek 2000 óta (Schleicher 2019).

\section{A fiúk és lányok teljesítménye közötti különbség lehetséges magyarázatai Biológiai megközelítés}

Az olvasás területén a nemek közötti különbség biológiai megközelítése azokat a veleszületett vagy az érés következtében a hormonális változásokkal párhuzamosan kialakuló tényezőket hangsúlyozza, amelyek a kognitív képességeket befolyásolják (Lassú, F. 2009). Tapasztalat, hogy a lányok általában korábban kezdenek el beszélni, mint a fiúk, gyorsabb a nyelvi fejlődésük, a fiúknál viszont gyakoribb a nyelvi és beszédbeli zavarok megjelenése. A beszédprodukciót és beszédmegértést érintő pszicholingvisztikai kísérletek is azt igazolták, hogy a lányok többségének anyanyelvi szintje az egyes életkorokban általában magasabb (Gósy 2005), mint a fiúké, a lányoknál tehát gyorsabb a verbális készségek - köztük az olvasási készség - kialakulása (Gósy 1997). A fiziológiaineurológiai magyarázatok közé tartozik a sokat vitatott corpus callosum szerepe, amely az agy bal és jobb féltekéjét köti össze, s a lány újszülötteknél fejlettebb, mint a fiúknál. A kutatások szerint a lányok agyában a fiúkénál kiterjedtebb területeken történik a szenzoros ingerek feldolgozása, korábban és nagyobb mértékben fejlődnek azok az agyi területek, amelyek a nyelv értésével és produkciójával vannak összefüggésben (Lassú, F. 2009).

Ha elfogadjuk, hogy a lányok nyelvi előnyökkel rendelkeznek, akkor ennek következménye lehet olvasási fölényük, sőt viselkedésbeli, érdeklődésbeli különbségek is magyarázhatók neurológiai alapon. A neurolingvisztikai kutatásokból tudjuk, hogy a bal agyfélteke felelős a nyomtatott szövegek megértéséért, a jobb pedig a képi információ feldolgozásáért. A nyomtatott szövegek a bal hemiszférához szólnak, míg például tévénézéskor a jobb hemiszféra aktivizálódik hangsúlyosabban. Általában véve a férfiaknál a jobb agyfélteke működése a meghatározóbb, míg a nőknél a bal. Ezen feltételezések magyarázzák azt, hogy a fiúk érdeklődése az agyi különbségek miatt elsősorban a vizuális ingerek felé fordul, így a vizuális média és a számítógép jobban leköti őket, mint például az 
olvasás. A lányok érdeklődése nem ennyire képi, tehát szívesebben vesznek könyvet a kezükbe. Ez a különbség általában az iskolában is megmarad, amikor a gyerekek az írás és olvasás alapképességét sajátítják el (Kegyesné 2001).

\section{Szocializációs szempontok}

Említettük, hogy a lányok általában előbb kezdenek el beszélni, mint a fiúk. Ha pedig a kislány egyébként is nyitott a külvilágra, a nyelv korai megjelenése a környezet részéről ösztönös megerősítést indukál, ami tovább fejleszti a gyermek anyanyelvi szintjét.

A biológiai és szocializációs szempontokat egyaránt érinti, hogy az olvasási nehézségekkel küzdő fiataloknál a kutatások egy része szoros összefüggést talált az olvasási és szövegértési képesség hiányossága, valamint a magatartási nehézségek között. Egy 5-7 éves korú gyermekekkel végzett longitudinális vizsgálat eredményei szerint a magatartási és olvasási nehézségek olyan nagymértékben együtt járnak, hogy bármelyiket is célozzuk meg fejlesztési szándékkal, azzal a másikra is hatunk (Lassú, F. 2009). A kapcsolódási pont a kettő között a szociális nézőpontátvétel képessége. Az irodalmi szövegek olvasása szükségessé teszi a másik személy szempontjának megértését, a másik helyzetébe történő beleélést. A fiúk hátránya az empatikus beleélés képességében nemcsak a korábban említett veleszületett biológiai adottságokon múlik, hanem a tapasztalatok jellegén is. A kutatás szerint a fiúgyermekekkel sokkal ritkábban osztották meg szüleik érzéseiket, saját érzéseikről is kevesebbet kérdezték őket, ritkábban biztatták a fiúkat arra, hogy próbálják meg beleélni magukat mások helyzetébe. Ennek köszönhetően, valamint a veleszületett adottságaik, a hormonális és idegrendszeri sajátosságok miatt a fiúk már óvodáskorban is kevésbé empatikusak, mint a lányok, és ez a különbség serdülőkorra csak növekszik. Egyesek szerint a fiúk előnyben részesítik a mozgalmasabb, változatosabb, nagyobb társaságot (bandát) igénylő elfoglaltságokat. Kevésbé szeretik a magányos tevékenységeket, az olvasást, pedig ezzel fejleszthető a nézőpontátvétel képessége, másrészt a kutatások szoros összefüggést mutatnak a szépirodalom olvasása és az olvasási képesség, szövegértés képessége között. A biológiai megközelítés hívei szerint a fiúk kevésbé alkalmasak a csöndes elmélyülést és empatikus ráhangolódást igénylő szépirodalmi szövegek olvasására (Lassú, F. 2009). Ezt a nézetet osztva sok szülő eleve nem vesz annyi könyvet a fiának, mint a lányának. Erre utalnak Ábrahám Mónika azon eredményei, amelyek a fiúk és lányok saját könyvtárának nagyságára vonatkoznak. A vizsgálat eredményei alapján a 12-14 éves fiúk nagyobb részének (55\%) egyáltalán nincs, vagy 50-nél kevesebb könyve van, míg ez az arány éppen fordítva jellemző a lányokra, akik 60,5\%-ának van 50-nél több könyve (Ábrahám 2006).

Természetesen a nemek közötti különbségek tárgyalásakor nem hagyhatjuk figyelmen kívül azokat a tényezőket sem, amelyek a szocializáció során esetlegesen más mintákat közvetítenek az apa és az anya részéről. Egyes családokban például a kisfiúk az apa- és férfiszerep sajátosságának tartják a nemolvasást, ugyanis ezt a tevékenységet esetleg csak édesanyjuktól látják. A fejünkben gyakran megjelenő sztereotípia szerint, amelyet az olvasásszociológiai vizsgálatok is megerősítenek, az anya olvas, mond mesét a gyermekeknek. Csakhogy az elmúlt időszakban az apák esetében egyre markánsabban került előtérbe a gyermekeknek való mesélésre, illetve a velük való játékra fordított idő, ami a konkrét tevékenységek esetében a nemi szerepek jelentős átrendeződését eredményezte (Harcsa 2014).

Tóth Máté országos reprezentatív olvasásszociológiai felmérése szerint (Tóth 2019) az anya végzettségének szerepe sokkal meghatározóbb az olvasóvá válásban, mint az apáé, de mindkét szülő vonatkozásában egyértelmű tendenciákról tanúskodnak az eredmények. Az anyának nemcsak a foglalkozása, hanem az iskolai végzettsége is erő- 
sebben meghatározza például a kisgyerekeknek szóló meseolvasást, mint az apáé. Az anya iskolai végzettsége ebben a tekintetben fontosabb húzóerő, mint az apáé. A nők körében eleve magasabb arányban vannak a könyvtári tagok, és ez mintaként jelenik meg a gyerekeknél is.

Szintén szociológiai megközelítést igényel - hiszen a korábban említett biológiai megközelítés nem ad magyarázatot arra -, hogy Magyarországon a fiúk hátránya az oktatás színvonalának emelkedésével párhuzamosan csökken (a 8 osztályos gimnázium tanulói között minimálisra redukálódik, míg a kisebb, hátrányos helyzetű településeken jobban lemaradnak a fiúk a lányoktól a szövegértés tekintetében). Ez utóbbi összefüggésben van a szülők alacsonyabb iskolai végzettségével (ami a legerősebben befolyásoló tényező), de a könyvesbolt, könyvtár hiányával vagy szerényebb kínálatával is (Lassú, F. 2009).

A férfiak minden korosztályban kevesebbet olvasnak, és ez különösen igaz az alacsonyabb végzettségű, munkásosztálybeli férfiakra. Az ő mintájukat követve az ilyen családokban felnövő fiúk nagy valószínűséggel szintén könyvkerülőkké válnak. Az olvasás ezekben a társadalmi csoportokban nem számít férfias tevékenységnek (Mac an Ghaillra hivatkozik: Lassú, F. 2009). A „macsó csávók” („helyi menő csávók”) egy olyan szubkultúratípus (az iskolában), akik az iskolát rájuk kényszerített intézménynek, a tanulást értelmetlen tevékenységnek tartják. Ezekben a gyakran munkanélküliséggel sújtott közösségekben nem a tanulás vagy a munka számít az érvényesülés fő útjának.

\section{Pedagógiai szempontok}

Már az óvodában is?

Egy német kutatás szerint az óvodapedagógusok eltérő hatással lehetnek a korai literációs fejlődésre a lányokat és fiúkat tekintve (Wolter-Gluer-Hannover 2014). A vizsgált német óvodai csoportokban mindegyik óvodapedagógus nő volt. Az óvónők saját beszámolója alapján sokkal több tipikusan lányos tevékenységet ajánlottak, mint fiúsat, ráadásul a lányokat közelebb érezték magukhoz, mint a fiúkat. A közeli gyerekpedagógus kapcsolat viszont támogatta a korai literációs készséget, ami az egy év múlva mért betűzési készségben vált nyilvánvalóvá.

Kegyesné Szekeres Erika megfigyelései ugyanakkor óvodáskorban inkább az egyéni eltéréseket hangsúlyozzák a nemi különbségekkel szemben (Kegyesné 2001). A kisgyermekkor (4-5/6) olvasási fázisában a gyerekek képeskönyveket forgatnak, előnyben részesítik az állatokról szóló rövid történeteket. Jól érzékelhetőek az egyéni eltérések, nemi differenciálódás nem vagy csak kevésbé figyelhető meg, a különbség elsősorban a témaválasztásra vonatkozik.

Ezzel szemben egy nagycsoportos óvodások körében végzett - nem reprezentatív felmérés során (Szinger 2009a) feltételezésünk az volt, hogy az írásbeli viselkedést és írásos tevékenységeket tekintve már óvodáskorban kimutatható a nemek közötti különbség a lányok javára. Vizsgálatunk - egy nagyobb kutatás keretében (Szinger 2009a) - többek között ennek a hipotézisnek az igazolására irányult. A felmérés során a gyermekek írásbeliséggel kapcsolatos tudását, ismereteit vizsgáltuk, az alábbi szempontokat véve alapul: nyelvi tudatosság (szótagolási képesség, a mondat és szó fogalmának ismerete, fonématudatosság, a jelfunkció ismerete, vagyis, hogy a hang jele a betű); az írásbeliség funkciójának ismerete; a vizuális kommunikáció szokásai; az írásbeliséghez köthető technikai tudás (pl. eszközök, direkcionalitás, kvázi-olvasás, kvázi-írás); az írás-olvasás esemény gyakorisága (könyvnézegetés, a mesélés igénye a gyermek részéről, „mesélés” könyvből a társaknak); az olvasás szintje (nem ismeri a betűket, felismer, azonosít betűket, felismer, azonosít szavakat, szótagolva olvas, folyamatosan olvas, az olvasottak ér- 
telmét is felfogja); az írás szintje (a gyermek rajzain nem jelennek meg betűszerű ábrák, rajzain megjelennek betűelemek, le tud írni néhány nyomtatott nagybetűt, értelmes szavakat ír, a szavaknál hosszabb, elolvasható, jelentéssel bíró írásbeli produktumokat hoz létre, amelyek mondat- vagy szövegszerűek). Az összefüggések értékelésekor a matematikai-statisztikai módszerek közül a fiúk és lányok eredményeinek összehasonlítására a szignifikanciavizsgálatot választottuk. Megnéztük, hogy a fiúk és lányok teljesítménye között kimutatható-e szignifikáns különbség az alábbi területeken: nyelvi tudatosság (NYELVTUD), az írásbeliség funkciójának ismerete (IRF), a vizuális kommunikáció szokásai (VIZKOM), az írás-olvasás esemény gyakorisága (IROLVGY), az ezekből létrehozott összevont mutató az írásbeli kommunikáció (IRKOM), az olvasás szintje (OLVSZINT), az írás szintje (IRSZINT). Itt is megnéztük a szórást a két csoportban, majd a kétmintás tpróba, illetve a Welch-próba alapján kerestük az átlagok közötti szignifikáns eltérést 95\%-os szinten. Az eredmények alapján a nyelvi tudatosság kivételével minden területen szignifikáns eltérés mutatható ki a lányok javára, vagyis már óvodáskorban megmutatkozik az a különbség, ami a tapasztalatok szerint az iskolában is jelen van az olvasásés írástanulás során (Szinger 2009a; 2009b).

\section{1. számú diagram: a nemek átlaga a különböző területeken}

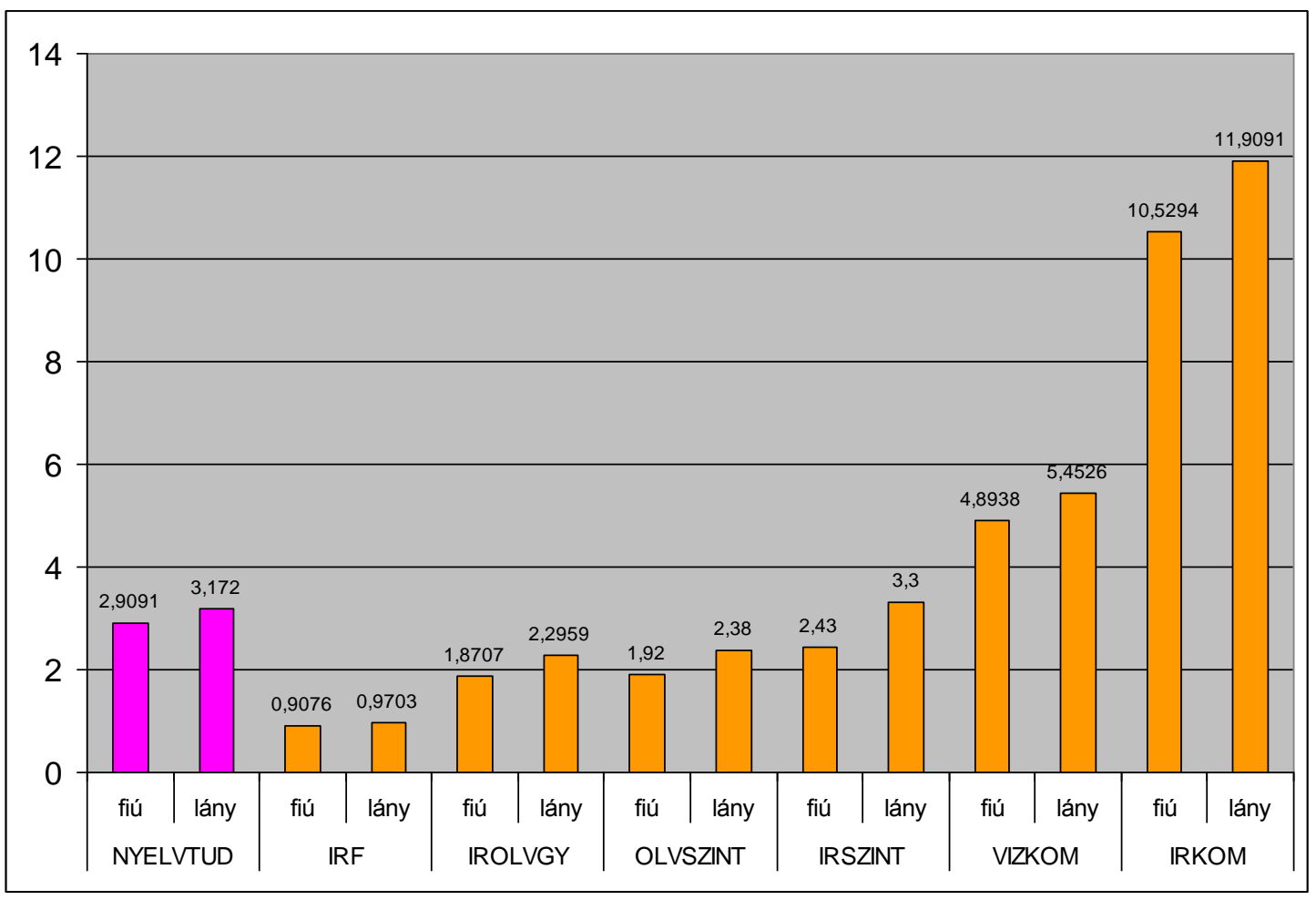

\section{Mi történik az iskolában?}

Egy észak-walesi általános iskolában végzett felmérés arra volt kíváncsi, hogy a 6-7 éves fiúk hogyan viszonyulnak az oktatáshoz, iskolához (Hamilton-Jones 2016). Azt is vizsgálták, hogy a pedagógusok mit gondolnak a fiúk tanulásáról, és milyen nemi különbségeket vesznek észre. Bár ebben a korosztályban a fiúk általában pozitívan viszonyulnak az iskolához és a tanuláshoz, észrevettek néhány olyan sajátosságot, amit ha figyelmen kívül hagynak, az a fiúk demotiváltságához és alulteljesítéshez vezethet. Ezen tényezők közé tartozott például az elnőiesedett oktatási szektor negatív hatása, ami Magyarországon is probléma. Ha találunk is elvétve férfi tanítókat az elemi oktatás alsó fokán, a tantárgyak tipikus felosztása a tanítónőkhöz rendeli az éneket, olvasást, írást, a férfi tanítóknak jut a matematika, környezet, technika és testnevelés. A walesi vizsgálatban to- 
vábbi fontos tényezőnek számított a fiúk viszonyulása az olvasáshoz (írásbeliséghez), az eltérő tanulási stílus, és hogy a fiúk előnyben részesítik a képernyőalapú, digitális eszközöket.

Ez utóbbit erősíti meg egy svédországi kutatás eredménye is (Rasmusson-AbergBengtsson 2015). A svéd PISA-adatokat használták fel ahhoz, hogy feltárják, a számítógépes játékok hogyan kapcsolódnak a digitális olvasási teljesítményhez és a nemhez. A digitális literációnál a fiúknál tapasztaltak előnyt, amit a számítógépes játékokra fordított idővel hoztak összefüggésbe.

A nemekkel kapcsolatos olvasási sztereotípiák viszont a lányoknak kedveznek (Retelsdorf-Schwartz-Asbrock 2015). A vizsgálat célja annak kiderítése volt, hogy a tanárok nemekre vonatkozó sztereotípiái az olvasással kapcsolatban milyen hatással vannak a fiúk olvasási önképére. A longitudinális vizsgálat során kétszer került sor adatgyưjtésre az 5. osztály elején és a 6. osztály második félévében. A minta 54 tanárból és 1358 diákból állt. Az olvasási önképet, az olvasási teljesítményt és az iskolai előrehaladást vizsgálták. Negatív összefüggést találtak a tanárok első felmérés során tapasztalt nemi olvasási sztereotípiája, valamint a fiúk olvasási önképe között a második vizsgálat során.

\section{A PISA-vizsgálatok tanulságai}

A fiúk kevésbé kompetens olvasók, mint a lányok - és ez minden országra érvényes, ahol PISA-vizsgálatot végeztek 2000 óta. A lányok dominanciája különösen az alábbiakra vonatkozik:

- a tisztán írásos információra (szemben a nem összefüggő szövegekkel, amelyek kombinálják az írásos információt számokkal, diagramokkal, táblázatokkal stb.),

- a szövegértés megerőltetőbb területeire (például egy értékelés megalkotása, reflektálás egy szöveg tartalmára vagy formájára és annak értékelése) (European Commission: Eurydice 2011).

Ha szeretnénk röviden összefoglalni a PISA-eredmények nemi vonatkozásait, akkor általánosságban az alábbi mondható el: a fiúk és a társadalmi-gazdasági szempontból hátrányos helyzetű tanulók kevésbé elkötelezettek az olvasás iránt, mint a lányok és a társadalmi-gazdasági szempontból előnyösebb helyzetben lévő tanulók. A különböző olvasási eszközök között a szépirodalom olvasása mutatja a legerősebb kapcsolatot az olvasási teljesítménnyel. Ugyancsak pozitív kapcsolat van az online olvasás és a hagyományos nyomtatott szövegben való jártasság között. Ami viszont témánk szempontjából talán a legfontosabb üzenet: A PISA minden résztvevő országában minél inkább élvezik a tanulók az olvasást, és minél inkább elköteleződnek a kedvtelésből történő olvasás iránt - akár hagyományos, akár online olvasásról van szó -, annál jobb az olvasásban való jártasságuk. „Az egyéni szint változásra legfogékonyabb faktora a tanuló elmélyülése az olvasási teljesítményekben. (...) Ezért, amikor a fiúk szeretnek olvasni, változatos dolgokat olvasnak és alkalmazzák a szövegértési stratégiákat, a teljesítménynek magasabb szintjét érhetik el az olvasásban, mint a lányok." (European Commission: Eurydice 2011) Vagyis akik saját kedvtelésükre is olvasnak, szignifikánsan jobban teljesítenek a PISAteszteken minden résztvevo országban. Ugyanakkor „tudjuk, hogy szoros összefüggés van a fiúk olvasással kapcsolatos attitűdje és szövegértési teljesítménye között. A fiúk olvasással kapcsolatos érzései erőteljesen befolyásolják azt is, hogy milyen gyakran olvasnak. Azoknak a fiúknak, akiknek az olvasásról negatív a véleményük, negatív a motivációjuk mind az iskolában, mind a szabadidőben a szórakozási célú olvasással kapcsolatban. Az olvasás elutasítása, sajnos, más készségek fejlődését is hátráltatja" (Brozo 2019: 142). 2015-ben a nemek közötti különbség 27 pont volt, amihez a magyar ered- 
mények nagyon közel álltak, a lányok átlagosan 25 ponttal teljesítettek jobban a fiúknál (Lannert-Kaderják-Németh 2019: 237). A 2018-as PISA-felmérés eredményei alapján a szövegértési képességekben mért nemek közötti különbségek csökkentek ugyan Magyarországon, de nem azért, mert a fiúk teljesítménye javult, hanem mert a lányoké romlott (Schleicher 2019: 32).

\section{Jó és ígéretes gyakorlatok}

Az EU Szövegértési Készséggel Foglalkozó Magas Szintű Szakértői Csoportjának 2012-es jelentése hívta életre az ELINET-projektet, melynek egyik célkitűzése jó gyakorlatok gyűjtése volt ${ }^{2}$. A projekt munkadefiníciója szerint a jó gyakorlat kutatási eredményekre épül, van elméleti háttere, és valamilyen formában már értékelték. Az ígéretes gyakorlatnak is van elméleti háttere, kutatási eredményekre alapoz, ám nincs róla értékelés a birtokunkban. Az ilyen típusú gyakorlat szolgálhat új projektek inspirációjaként. A jó vagy ígéretes gyakorlat a projekt elvárásai szerint elsősorban olvasási/írási nehézséggel küzdőkre fókuszál (az iskoláskor előtti programok mind ilyennek tekinthetők, hiszen valamennyi kockázati tényezőre figyelnek); kutatási eredményekre épül, világos célokat tűz ki; a megvalósítás dokumentált, azaz világos információkkal szolgál a megvalósított tevékenységekről, a résztvevőkről, a célcsoportról stb.; a projekt értékelése, a célcsoportra gyakorolt hatásának dokumentálása elérhető; adaptálható, azaz hasonló helyzetekben ugyanott vagy más helyszíneken megvalósítható; a program eredményeiről szórólap, kézikönyv vagy egyéb anyagok elérhetők nyomtatva vagy az interneten.

Az alábbi példák a fiúk olvasási motivációjának és szövegértésének javítására kidolgozott jó/ígéretes gyakorlatok.

\section{Olvassanak a férfiak gyermekeiknek! Olvasó apukák az óvodában}

A PISA-felmérések szerint a tanulási eredményeket tekintve Finnország a vezető országok közé tartozik. A fiúk és a lányok közötti szakadék azonban nagyobbnak tűnik, mint más országokban; az olvasásban gyengén teljesítők többsége Finnországban fiú. Az olvasás iránti attitűd is a harmadik legrosszabb a listában a PISA-ban részt vevő országok közül, és jelentősen elválik a többi, kimagasló eredményt mutató országtól e tekintetben.

A projekt szerint a fiúk érdeklődését az olvasás iránt leginkább egy férfi ideál, egy számukra szerepmodellként szolgáló felnőtt férfi keltheti fel. Így ebben a finn kampányban a résztvevőket pont erre kérik: legyenek olyan felnőttek, olyan modellek, akiktől a gyerekek tanulhatnak. Nagyon sokat jelent a gyerekeknek, ha látják, hogy egy könyv milyen izgalmat vált ki egy felnőttből, vagy hogyan mélyül el egy felnőtt az olvasott könyvben.

Az „Ajándékozz nekünk egy történetet!” elnevezésű finn kampány ${ }^{3}$ arra buzdította a férfiakat, hogy az óvodák és iskolák mindennapi olvasási tevékenységeibe kapcsolódjanak be, s ők maguk is olvassanak. Olvasóalkalmakat szerveztek novemberben, a férfiak hetén, mely az apák napjával végződik. Könnyen lehetett megfelelő időpontot találni mind az óvodában, mind az iskolában arra, hogy olvassanak. Saját gyermekeiknek, unokáiknak olvashattak az apukák és a nagypapák, például a reggeli gyülekező alatt. Választhattak, hogy egy szép mesét vesznek elő, vagy valós történetet mondanak el, az időpontban pedig megegyeztek az óvodapedagógussal vagy az osztályfőnökkel. A pedagógus hívta meg az édesapákat, segített nekik kiválasztani a megfelelő olvasmányt, és szükség esetén segítséget nyújtott. A felolvasás hossza általában 15 perctől kezdve egy

\footnotetext{
${ }^{2}$ Erről bővebben lásd: www.eli-net.eu

${ }^{3}$ Erről bővebben lásd: http://www.eli-net.eu/good-practice/examples-of-goodpractice/detail/project/encouraging-men-to-read-for-their-children
} 
egész tanórányi is lehetett. A résztvevő édesapákat arra kérték, hogy otthon folytassák az olvasást akár ugyanazzal a szöveggel, akár másikkal. Óvodák és iskolák egyaránt bekapcsolódtak a kampányba, mely csatlakozott a Finn Szülői Szervezet VALOSAprojektjéhez, a Finn Oktatási és Kulturális Minisztériumhoz és az Oulu Egyetem Lukuinto („Az olvasás élvezete”) programjához.

1) A Lukuinto-program a Kulturális és Oktatási Minisztérium hároméves projektje (2012-2015) az Oulu Egyetem Bölcsészet- és Neveléstudományi Tanszékeivel együttmúködve. A program célja a gyerekek és fiatalok literációs készségeinek javítása volt.

2) A VALOSA-projektben a szülők 7-13 éves gyermekeik közösségi és társadalmi aktivitását, bevonását tűzték ki célul. A VALOSA-projekt is három évig tartott, a Finn Szülői Szervezet működtette.

2014-ben közel 50 iskola és óvoda kapcsolódott be a kampányba. A becslések szerint azonban mintegy 200 helyen voltak olvasóalkalmak (a projekt anyagait különböző címekről kb. 200-szor töltötték le), melyeket bejelentés nélkül szerveztek meg. Az óvodák és iskolák az internetről letölthető, illetve nyomtatható útmutatót és anyagokat kaptak az apás vagy nagypapás olvasói alkalmak szervezéséhez.

A kampányt könnyű megvalósítani az óvodák és iskolák mindennapjaiba illesztve. A projekt természetes módon közelebb hozza egymáshoz a szülőket és a gyerekeket, miközben a férfiak kulcsfontosságú szerepet töltenek be a gyermekek olvasásra motiválásában.

\section{Fiúk és könyvek (Boys \& Books)}

A projekt ${ }^{4}$ célja a 6 és 18 év közötti, keveset vagy egyáltalán nem olvasó fiúk olvasási motivációjának növelése. Németországban még a PISA-eredmények előtt nyilvánvalóvá vált, hogy a fiúk olvasási teljesítménye sokkal alacsonyabb, mint a lányoké.

A Boys \& Books egy internetes platform, ahol fiúknak szóló könyvek ajánlásai olvashatók az általános iskolástól a középiskolás korosztályig. A Boys \& Books az olvasási különbségekről szóló kutatási eredményekre épít, melyek szerint a lányok gyakrabban és tovább olvasnak, mint a fiúk; a lányok más könyveket, magazinokat, digitális szövegeket olvasnak, mint a fiúk, tehát a fiúk és a lányok olvasási szokásai eltérnek egymástól. Az olvasás mást jelent a lányoknak, mint a fiúknak: a lányok örömüket lelik benne és élményszerzésből olvasnak; a lányok jobban teljesítenek olvasásból, mint a fiúk, főként, ha nehéz olvasási feladatokról van szó.

A Boys \& Books weboldal ${ }^{5}$ főként felnőttekhez szól: azokhoz a szülőkhöz, tanárokhoz, könyvtárosokhoz, szociális munkásokhoz, akik a fiúk olvasóvá nevelésében bármilyen szerepet betölthetnek. A weboldal fiús olvasnivalókat, az olvasástanításhoz módszertani ajánlásokat, ötleteket kínál, hogy hogyan lehet az adott könyvet az irodalomtanításba beemelni. Mind a műfaj szerint csoportosított könyvajánlók, mind a módszertani ötletek olvasóközpontú irodalomkritikai megközelítésben íródtak. A weboldalt az emeli ki a többi hasonló tartalmú platform közül, hogy a gyermekek és tinédzserek olvasási szokásairól szóló empirikus kutatások eredményei alapján készült.

A projekt 2012-ben indult Németországban a Kölni Egyetem szakmai támogatásával, s a weboldalt is az egyetem olvasáskutatói működtetik. A projektcsoportot két projektmenedzser vezeti, 4 asszisztens s mintegy 60 önkéntes vesz részt a munkában. A könyvek kiválasztását és értékelését, illetve a módszertani ajánlások elkészítését gyermek- és ifjúsági irodalmat kutatók csoportja végzi. Minden egyes műfajhoz könyvkritikasablont

\footnotetext{
${ }^{4}$ Erről lásd bővebben: http://www.eli-net.eu/good-practice/examples-of-good-practice/detail/project/boysbooks

${ }^{5}$ www.boysandbooks.de
} 
készítenek, amely a könyvajánlások megírásához nyújt segítséget. Évente kétszer a 20 legjobb könyvet értékelik (ötöt-ötöt korcsoportonként: 8+, 10+, 12+, 14+). A zsűriben könyvtárosok, könyvesboltok munkatársai, szerzők, kutatók és oktatási szakemberek vannak. Az értékelés szempontjai többek között a könyvborító, a szöveg stílusa és nyelvezete, a cselekmény és a főszereplők.

\section{Hazai ajánlók}

A Boys \& Books weboldal is felhívja a figyelmet a következőkre: ahhoz, hogy egy fiút elkötelezett olvasóvá tegyünk, elengedhetetlen, hogy neki szóló olvasmányokat ajánljunk. Ma már szerencsére több olyan pozitív példával találkozhatunk, ahol az olvasáspedagógiai program fontos eleme, hogy odafigyeljenek a nemek közötti - többek között érdeklődésbeli - különbségekre, és az olvasmányok gondos megválasztásával motiválják mindkét nemet az olvasásra. Ilyen sikeres kezdeményezéssel találkozhatunk többek között finn és német iskolákban, de hazánkban is, például a Magyar Olvasástársaság honlapján a gyermekirodalmi adatbázisban nemcsak életkor alapján, de nemek szerint is találunk könyvajánlásokat ${ }^{6}$. Nagyon fontos lenne, hogy a tanulók (a fiúk is) részt vehessenek az iskolai közös (és nem kötelező) olvasmányok kiválasztásában. Ráadásul a kortárs csoport hatása is fontos tényező mind a könyvek kiválasztásában, mind az azokról folytatott diskurzus szempontjából. Egy-egy regény, pláne sorozat szinte „végig tud söpörni" egy generáción. Ugyanakkor Gombos Péterék írásából (Gombos-Hevérné-Kiss 2015) tudjuk, hogy Magyarországon az a sajátos helyzet figyelhető meg - immár évtizedek óta -, hogy alig vannak „generációs könyvek”, a közös élményt még mindig az iskolai irodalom jelenti, amely ugyanakkor meglehetősen kevesek számára jelent olvasmányélményt. Ezért különösen örvendetes, hogy az „Én könyvtáram” projekt mintaprogramjai között megtalálható a „Könyvsú-go! Válassz könyvet könnyen!”7 jó gyakorlat, ahol a résztvevők egymásnak ajánlhatnak könyveket egy folyamatosan bővülő adatbázisban.

Szerencsére a magyarországi könyvtáraknak is számos olyan jó gyakorlatuk van, amellyel a fiúkat (is) meg lehet fogni, érdemes például „Az én könyvtáram” honlapján böngészni a jó gyakorlatok között ${ }^{8}$. Motiváló tényező lehet a programban az IKTeszközök, online applikációk használata kreatív feladathelyzetekkel, azonnali visszacsatolási lehetőségekkel, egyéni haladási ütemmel, egyéni sajátosságokra való reflektálással. Motiváló erővel bírhat a gamifikáció (játékosítás) alkalmazása, de hasonlóképpen a történelmi vagy detektívjátékok, a képregények és a robotika is. Lehet, hogy a programok nem mindegyike fókuszál elsődlegesen az olvasásra, de ha a gyerekeket sikerül becsábítanunk a könyvtárba, ott jól érzik magukat, működőképes lehet a transzferhatás. Ne feledjük, nemcsak fiúkról van szó, hanem a z és alfa generáció tagjairól általában, akik a telekommunikáció és az internet világának szülöttei, úgynevezett digitális gyerekek. Mindez természetesen nem csak a könyvtári programokra vonatkozik. A fiúk motiválásának egyik eszköze lehet az iskolában is, ha olyan szövegekkel, médiával találkoznak, amit szívesen olvasnak, használnak az iskolán kívül. A z generáció tagjai szívesen olvasnak közösségi oldalakat, online számítógépes magazinokat, videojátékokat. Motiváló és önértékelésüket javító megoldás lehet számukra, ha az őket körülvevő digitális írásbeliség médiumai és szövegei a tanórák anyagaiba is beépülnek. „Ahhoz, hogy a fiúk lelkes olvasók és tanulók legyenek, először is azt kell látniuk, hogy tanáraik és az iskolai dolgozók számára az olvasás érték s eszköz mind az élményszerzésben, mind az egyén fejlődésében. Úgy tudjuk ezt az értéket leginkább továbbadni, ha az iskolai könyvtárakban és

\footnotetext{
${ }^{6}$ A Gyermekirodalmi adatbázis itt érhető el: http://ki2.oszk.hu/gyerekirodalom/

${ }^{7}$ A program oldala: https://konyvsu-go.gvkik.hu/

${ }^{8}$ A jó gyakorlatok leírásai itt találhatók: http://www.azenkonyvtaram.hu/fejlesztes
} 
a tantermekben ott tornyosulnak a különböző, számos témát érintő, különböző nehézségi szintű, érdekes könyvek, a tanulók azok közül maguk választhatnak, és az iskolában van idő biztosítva a könyvekkel való ismerkedésre." (Brozo 2019: 149) A kamaszok számára motiváló lehet az is, ha kiválaszthatják, hogy mit és hogyan szeretnének olvasni. A megnövekedett felelősség és függetlenség érzése jobb teljesítményre ösztönzi őket. A fiúk számára a közösséghez tartozás érzése fontos tényező, így az olvasásban és a tanulásban a pár-, csoportmunka, projektek kidolgozása az elmélyülésre jó hatással van.

\section{A „Futball találkozása a kultúrával” projekt}

A „Futball találkozása a kultúrával” egy németországi olvasásprojekt, melyet a Nemzetközi Írás-Olvasási Kampány (LitCam) kezdeményezett 2007-ben. A futballt, az írásolvasási tevékenységeket és kulturális eseményeket azért kapcsolják össze, hogy a tanulási nehézségekkel küzdőket olvasásra ösztönözzék, fejlesszék nyelvi képességeiket, illetve nyitottabbá tegyék őket, segítve a társadalomba való könnyebb beilleszkedésüket. A „Futball találkozása a kultúrával” arra a meggyőződésre épült, hogy a futball és a tanulás, a kultúra összekapcsolása sok gyereket motivál, akik így elfogadóbbá, érdeklődőbbé válnak a tanulás és az olvasás iránt. A tanulás és mozgás kapcsolatára vonatkozó kutatási eredményeket is beépítették a programba annak kidolgozói.

A résztvevő gyerekek mind hátrányos helyzetű, gyakran bevándorlócsaládokból származtak. A program a gyerekeket elsősorban nyelvi képességeik fejlődésében támogatta, de fejlesztette az együttmüködési készségüket, növelte önbizalmukat, fegyelmezettségüket is. A program kulturális része messze túlmutatott a gyerekek addigi lehetőségein.

A programokon összesen mintegy 1050 gyerek vett részt, 8-14 éves tanulókat vontak be a projektbe, minden évben 24 tanulót, akik két-két csoportban (12-12 fő) dolgoztak. A diákcsoportok hetente kétszer találkoztak tanítás után, és az írás-olvasási készségeiket focitudásukkal együtt pallérozták. A fociedzések után speciális fejlesztőórák következtek. A futballedzéseket a helyi, jó nevű fociklubbal együtt tartották. A speciális órákat a résztvevők igényei alakították, de ezek főként anyanyelvi fejlesztő foglalkozások voltak, ahol a futball gyakran volt téma, például focis könyveket olvastak, míg a matematikafeladatokban fociliga-táblázatok szerepeltek. Havonta egyszer a gyerekek kulturális programon vettek részt, ami lehetett múzeumlátogatás, rap-költészeti workshop vagy egy könyvtárlátogatás. Minden tanév végén valamennyi csoport számára rendeztek egy bajnokságot - mindig más helyszínen.

A programba bevont tanárok (német) anyanyelvi fejlesztőórákat tartottak, illetve a kulturális eseményekre is ők kísérték el a csoportot. Részben azonos anyagokból dolgoztak (pl. Deutsch Stars), részben saját anyagaikat használták. A program végül egységes tananyagot dolgozott ki a tanárok számára. A digitális kompetencia fejlesztéséhez az Essen/Duisburg Egyetem által kidolgozott kézikönyvet használták. A sikeres projektet 17 iskolában, 10 németországi városban próbálták ki. A Bundesliga-Stiftung és más helyi szponzorok biztosították a projekt megvalósításához szükséges támogatást.

A „Futball találkozása a kultúrával” programot 2011/2012-ben úgy értékelte a PH Karlsruhe, hogy a futballedzés jó hatással volt a gyerekek tanulmányi előmenetelére és teljesítménymotivációjukra (érvényesült az edző szerepmodell funkciója). Az edzések erősítették önbizalmukat, az elfogadás érzését, valamint javult a résztvevők viszonya a tanuláshoz és a kultúrához.

2012-ben a programot értékelte a PHINEO, egy független nonprofit értékelő cég is, és a program megkapta a PHINEO címkét. 
„Az igazi férfiak”: egy amerikai jó gyakorlat

Miért van az, hogy a (főként kamasz) fiúk nem tartják az olvasást férfias tevékenységnek? Az egyéni és kulturális identitás a társas kapcsolatokban formálódik, s így van ez ebben a kérdésben is. Az Amerikai Egyesült Államokban egy felmérés megmutatta, hogy afroamerikai hetedikes, nyolcadikos fiúk önmagukról mint olvasókról negatív képet alkottak, mert szüleik szerint a lányok azok, akik jól tudnak olvasni (Brozo 2019: 46). Finn kutatók azt vizsgálták, hogy iskolás fiúk hogyan használják az erőszakot, a fizikai erőnlétet, az anyagi helyzetet, a teljesítményt az egymás közötti hatalmi pozícióik kialakításában és a tisztelet kivívásában. A kutatás végső célja az volt, hogy ezen sztereotipikus, férfias tulajdonságok helyett a hatalom és az erő igazságos és felelősségteljes használata legyen az érték, s eszerint változzék meg a fiúk énképe (Brozo 2019: 47). NagyBritanniában a homofób, nőgyülölő és agresszív magatartás középiskolás fiúk körében nem annyira volt meghatározó a férfiasság vagy a dominancia tekintetében. Azonban számos, férfiasnak tartott viselkedési minta a státusszal függ össze: a karizma és a hitelesség a fiúk közötti hierarchia tekintetében két fontos elvárás (Brozo 2019: 46). Jó példa is van arra, hogyan tudják a kortársak a kamasz fiúknak az önmagukról mint olvasókról alkotott képét javítani: felzárkóztató osztályból normál tantervű osztályba küzdötték fel magukat középiskolás tanulók - főként fiúk -, akiket jobban teljesítő társaik, tanáraik segítettek a tanulásban. Az osztály befogadta őket, és ezek a személyes kapcsolatok nagymértékben hozzájárultak ahhoz, hogy az olvasással kapcsolatos önértékelésük javuljon. Ezek az eredmények azt jelzik, hogy szövegek által és szövegfeldolgozó órák, programok révén közelebbi kapcsolatba lehet és tudunk lépni a fiúkkal; az önmagukról mint olvasókról és mint férfiakról alkotott képet meg lehet változtatni. Ehhez nagyon fontos, hogy olyan szövegvilágot kínáljunk számukra, amely vonzó és elmélyülést eredményez.

„Az igazi férfiak” (Brozo 2019: 53-88) egy olyan nyolchetes, az Amerikai Egyesült Államokban megvalósult program volt, melyet a fenti igény és felismerés hívott életre. A programban hetedik osztályosok, elsősorban fiúk vettek részt. A cél az volt, hogy miközben olvasási készségük javul a program során, az önmagukról mint olvasókról és férfiakról alkotott képük is pozitív módon változzék.

A programot három tanár dolgozta ki és vezette; kettő közülük az iskola tanára volt, valamint egy olvasáskutató, aki korábban ebben az iskolában már végzett tanácsadást, illetve az egyik, a programban dolgozó tanár egyetemi oktatója is volt. A program tervezésekor a három szakember kiemelten fontosnak tartotta, hogy az irodalom a tanulók számára a férfiasság kritikai megközelítésének eszközéül szolgáljon; a populáris kultúrában és médiában megjelenő sztereotip férfiképet kritikusan tudják szemlélni a tanulók, és a program támogassa az elmélyült olvasást és tanulást.

A projektet a tanév utolsó nyolc hetére tervezték, hetente két napot töltöttek ezzel a programmal a tanulók és tanáraik. A program középpontjába Walter Dean Myers: Scorpions című regénye került, amely egy New York-i fiúbanda története, s amelyben iskolai lövöldözés történik. A regény két főszereplője szintén hetedikes, az egyik afroamerikai, a másik latin-amerikai (akárcsak többen az osztályból). A történet helyszíne Harlem közelében van, $s$ több tekintetben hasonlított a programban részt vevő tanulók lakóhelyéhez. A regényben a szegénység, az apa nélküli család éppúgy meghatározó a szereplők életében, mint a program tanulói számára. A három szakember úgy gondolta, hogy ez a könyv kiváló eszköz arra, hogy az elmélyült olvasást megteremtse, s lehetővé váljék a férfiasságról alkotott negatív összkép megváltoztatása.

A regény eseményei és szereplői köré tervezett programmal az volt a tanárok célja, hogy a tanulók számára lehetőséget teremtsenek arra, hogy saját mindennapi élménye- 
ikre reflektálhassanak a történet kapcsán társaikkal (elsősorban fiúkkal) közösen egy csoportban, ahol az erőszak és az önzés elfogadott férfi tulajdonságok. A résztvevő tanulók közül csupán ketten voltak lányok, a többiek mind fiúk. Mivel azonban a lányok ugyanebben a közösségben éltek, osztoztak fiútársaikkal abban, hogy mi számít férfias viselkedésnek, tulajdonságnak. Az osztályba járók többségének olvasási nehézségei voltak.

A program kezdetén, még az olvasás megkezdése előtt, a tanulók egy tízpontos, a tipikus férfias viselkedésről szóló listát kaptak, s igen/nem/talán válaszokat kellett adniuk; minden állításban az erőszakos viselkedés a férfiasság velejárójaként fogalmazódott meg. Ezt követően került sor egy beszélgetésre a könyvről, amikor az egyetemi oktató felolvasott egy rövid, izgalmas részletet a regényből. Ezután minden tanuló kapott a könyvből egy példányt (a könyveket az osztályteremben tartották a program ideje alatt), átfutották, megnézték, milyen hosszú, megkeresték a felolvasott részletet. A három szakember elmondta a program célját a tanulóknak: a jó és rossz döntések következményeiről lesz szó, vendégelőadókkal fognak találkozni és beszélgetni, lesz írásbeli feladat is, a végső cél pedig, hogy lássák és megértsék a pozitív férfias viselkedés jellemzőit, s rájöjjenek, milyen az igazi férfi.

Az első héten ötletelés zajlott a médiában közvetített igazi férfimodell és a tanulók által igazi férfinak tekintett személy tulajdonságairól. Ezeket egy-egy pókhálóábrában gyűjtötték össze, majd összehasonlították a médiában közvetített imázst az általuk igazinak tartott férfi ideáljával.

A második héten egy újabb olvasás előtti feladatot - benyomások leírása a történetről - kaptak a tanulók. Az elolvasandó részből kaptak nyolc szót, s az volt a feladatuk, hogy párban írjanak egy rövid bekezdést a nyolc szó felhasználásával arról, mi fog történni a regényben. Ezeket a bekezdéseket felolvasták a társaiknak. Olvasás közben összehasonlították saját elképzelésüket a regénnyel; sikerült motiválni őket az adott rész elolvasására.

A harmadik héten először anticipációs feladatot kaptak a tanulók: állításokról kellett eldönteniük olvasás előtt, hogy igazak vagy hamisak, majd olvasás után visszatértek ezekhez az állításokhoz. Ezután kaptak egy részletet az adott fejezetből, és „Hasonlítsd össze! - Állítsd szembe!” módszerrel a jó és rossz döntésekről folytattak mini vitát. Végül magazinokból, újságokból vágtak ki képeket férfiakról különböző tevékenységek közben, és két oszlopba, „jó” és „rossz” felirattal felragasztották azokat.

A negyedik héten a hetedikesek egy campustúrán vettek részt: ellátogattak arra az egyetemre, ahol a programot vezető egyetemi oktató tanít. Részt vettek az egyik tantárgyi írásbeliség módszertana órán, ahol olvastak, és olvasási stratégiákat mutattak be nekik. Az egyik stratégia a „pattogatott kukorica”, melyet összegzéshez használnak. Valamelyik tanuló mond egy részletet a történetből, egy másiknak a történetnek megfelelően folytatnia kell, és így tovább. Teljesen véletlenszerűen kezdi valaki, és ugyanígy véletlenszerű a folytatás is. A másik stratégia, amivel megismerkedtek a hetedikesek, a „Mindentudó Professzor”. Ehhez tartozik egy jelmez is: fehér köpenyt, Groucho-maszkot (vastag, fekete keretes szemüveg, vastag szemöldök, bajusz, nagy orr) viselnek egy négyfős csapat tagjai. Kapnak egy kérdést a többiektől a történetre vonatkozóan, és úgy kell válaszolniuk, hogy mindenki egy-egy szót mond a válaszmondatból, az utolsó pedig a mondatvégi írásjelet mondja. A történet eseményeinek összefoglalása ezzel a két stratégiával humorossá tette az olvasottak felidézését; a tanulók monitorozták egymást, s nem tanári kérdésekre vártak. Mivel az összefoglalásért ők voltak a felelősek, sokkal aktívabban vettek részt a stratégiák használatában is. 
Az ötödik héten váratlan esemény történt. Korábban azt a feladatot kapták a tanulók, hogy írjanak egy levelet a regény főszereplőjének arról, hogy mit tegyen a nála lévő fegyverrel: használja-e, s ezáltal kivívja bátyja elismerését, vagy szabaduljon meg tőle. Éppen a fegyvertartás témájával készült foglalkozni a csoport, amikor az iskolarádión az igazgatónő egy hírt olvasott be egy iskolai lövöldözés két áldozatáról, és egyperces néma csendet kért az osztályokban. Másnap érvelő vitát rendeztek az osztályban; két csoportban fegyverbolt-tulajdonosként, illetve a helyi fegyverboltot bezáratni kívánó helyi lakosokként kellett érvelniük a tanulóknak.

A hatodik héten elkezdődtek a projektmunkák. A tanulók az alábbi lehetőségekből választhattak: filmplakát, egy jelenet bemutatása, agyagfigurák leírással, életnagyságú poszter valamelyik szereplőről, 3D-s helyszín valamelyik jelenethez.

A hetedik héten reflektív naplót írtak a tanulók. Egy levelet kellett írniuk a regényírónak arról, hogy mit tanultak a történetből.

A nyolcadik hét az „Igazi férfiak fináléja” nevet kapta: a program ünnepélyes zárására is ezen a héten került sor. Előzetesen a programban részt vevő egyetemi oktató olyan vendégeket hívott meg, akik sikeres férfiak egy-egy területen, s hoztak magukkal egyegy olyan szöveget is, amely számukra fontos, vagy az életükben meghatározó volt valamilyen szempontból. Az ünnepség bemutatkozással kezdődött, majd a tanulói projektmunkák bemutatásával folytatódott. A vendégek elmondták, mivel foglalkoznak, hogyan lettek sikeresek, és felolvasták a magukkal hozott idézetet. Mindegyik vendég élesen különbözött attól a férfiképtől, -modelltől, amelyet ezek a tanulók addig ismertek, s mindegyik kiemelte a bemutatkozásában, hogy az olvasásnak milyen döntő szerepe volt a magán- és szakmai életében egyaránt.

$\mathrm{Az}$ „Igazi férfiak” program egyik tanulsága, hogy ha olyan könyveket választunk, mint például a Scorpions, amely megszólítja a kamaszfiúkat, és olvasható a számukra, akkor ezek a tizenéves - akár olvasási nehézséggel küzdő - fiúk el tudnak mélyülni a szövegben, be lehet őket vonni kritikai beszélgetésekbe a médiáról, a férfiasságról, saját nemi identitásukról. Ha figyelembe vesszük, miről szeretnének olvasni, hallani, beszélgetni, akkor a számukra vonzó szövegekben el tudnak mélyülni. A másik tanulság az, hogy a tizenéveseknek olyan olvasási tevékenységekre van szükségük és igényük, melyek sikeressé teszik őket, és olyan tanulási környezetre, mely figyelembe veszi az iskolán kívül megélt tapasztalataikat.

\section{Összefoglalás}

A fiúk és lányok nyelvi, olvasási teljesítményének eltéréseire vonatkozó tudományos igényű megfigyelések, sőt az erre irányuló kísérleti eredmények is nemegyszer ellentmondóak (Gósy 2005). Csíkos Csaba például a nemzetközi vizsgálatokra hivatkozva (IEA, OECD, PISA) az egyéni eltéréseket hangsúlyozza a nemek közötti különbségekkel szemben Csíkos 2006). Tóth Máté reprezentatív vizsgálata szerint is a rendszeres olvasók körében csak egy árnyalatnyi különbség mutatkozott a lányok javára, a megrögzött nemolvasók körében viszont szignifikánsan felülreprezentáltak voltak a fiúk (Tóth 2019). Bármelyik vizsgálatot nézzük, a szociokulturális és gazdasági háttér vagy az egyéni eltérések természetesen markáns indikátorai az eredményeknek, ugyanakkor véleményünk szerint a nemek közötti különbségek olyan kérdéseket vetnek fel, amelyek megkerülhetetlen tényezői a pszicholingvisztikai kutatásoknak és az olvasáspedagógiának. A fiúk és lányok olvasás terén kimutatható különbségeit eddig leginkább iskoláskortól vizsgálták, az iskoláskor előtti időszak kevesebb figyelmet kapott. Az általunk bemutatott jó és ígéretes gyakorlatok viszont egészen kis kortól az iskoláskoron át hangsúlyozzák az olvasóvá válás segítésének fontosságát. 
Az iskola, a pedagógusok, illetve az oktatás valamennyi szereplőjének feladata az, hogy a fiúkban felkeltse és fenntartsa az olvasás iránti kedvet valamennyi iskolai szinten. A fiúk olvasás iránti motivációjának felkeltésekor két tényezőt együttesen érdemes figyelembe venni: egyrészt az egyéni érdeklődés, szükségletek, vágyak, törekvések megismerése minden olvasó esetében - legyen szó akár fiúról, akár lányról - fontos ahhoz, hogy olyan olvasnivalót kínáljunk számára, amely felkelti az olvasás iránti kedvét, másrészt a fiúk nemi identitásából fakadó társadalmi elvárások megértése is szükséges az olvasmányok kiválasztásakor. Az olvasás iránti motivációt a következő tényezők nagymértékben tudják javítani: önértékelés, érdeklődés, egy konkrét, adott szöveg megértéséhez szükséges stratégiák ismerete, iskolán kívüli írásbeliség, elérhető és érdekes szövegek, választási lehetőségek és együttműködés.

Ez persze nem feltétlenül jelenti azt, hogy ideális feltételek mellett felnövekedvén egy fiú töretlenül könyvmoly lesz. Hiszen ahogy Béres Judit is utal rá, „gyakran előfordul, hogy az irodalomgazdag, olvasásra ösztönző családi környezetből érkező kiskamaszok (főleg, ha fiúk) aktuális érdeklődése egy időre más szabadidős és társas tevékenységekre irányul, és csak pár év múlva találnak vissza az olvasáshoz" (Béres 2019: 86). De ne feledjük: a fiúk a lányoknál is jobb olvasásteljesítményre képesek, ha elkötelezett olvasókká tesszük őket, amelynek hatásos eszközei lehetnek a tanulmányban bemutatott jó és ígéretes gyakorlatok.

\section{Irodalom}

Ábrahám Mónika (2006): 12-14 éves gyerekek olvasási, könyv- és könyvtárhasználati szokásai. Új Pedagógiai Szemle, 56(1), 3-23.

Béres Judit (2019): Az olvasás szerepe a személyiség gazdagításában. A kisgyermekes családok és a helyi fiatalok könyvtári támogatása. In: Baráthné Hajdu Ágnes - Béres Judit (szerk.): Olvasásfejlesztés könyvtári környezetben. (Módszertani kötetek 2.) Bp.: Fővárosi Szabó Ervin Könyvtár, pp. 83-117.

Brozo, William G. (2019): Engaging Boys in Literacy : Evidence and Practice. Cambridge: Cambridge University Press

Csíkos Csaba (2006): Nemzetközi rendszerszintű felmérések tanulságai az olvasástanítás számára. In: Józsa Krisztián (szerk.): Az olvasási képesség fejlődése és fejlesztése. Bp.: Dinasztia Tankönyvkiadó, pp. 175-186.

European Commission - Eurydice: Teaching Reading in Europe 2011.

<URL: http://eacea.ec.europa.eu/education/eurydice/documents/thematic_reports/ 130EN.pdf) [2019. 09.02.]

Gombos Péter - Hevérné Kanyó Andrea - Kiss Gábor (2015): A netgeneráció olvasási attitűdje: 14-18 évesek véleménye könyvekről, olvasásról, irodalomról - egy felmérés tanulságai. Új Pedagógiai Szemle, 65(1-2), 52-66.

Gombos Péter (2019): A digitális generáció olvasási szokásai - a 2017-es reprezentatív olvasásfelmérés tapasztalatai. In: Baráthné Hajdu Ágnes - Béres Judit (szerk.): Olvasásfejlesztés könyvtári környezetben. (Módszertani kötetek 2.) Bp.: Fővárosi Szabó Ervin Könyvtár, pp. 149-192.

Gósy Mária (1997)): Beszéd és óvoda. Bp.: Nikol Gmk

Gósy Mária (2005): Pszicholingvisztika. Bp.: Osiris Kiadó

Hamilton, Paula Loise, - Jones, Louise (2016): Illuminating the 'boy problem' from children's and teachers' perspectives : A pilot study. Education, 44(3), 241-254.

DOI: $10.1080 / 03004279.2014 .903987$ 
Harcsa István (2014): Családi kohézió : A szülők és a gyermekek társas együttléte a mindennapok világában. Bp.: KSH

Kegyesné Szekeres Erika (2001): A fiúk és a lányok eltérő olvasási szokásairól. Iskolakultúra, 11(5), 31-37.

Lannert Judit - Kaderják Anita - Németh Szilvia (2019): Összehasonlító, elemző tanulmány a magyar diákok szövegértési kompetenciáiról, nemzetközi összehasonlításban. In: Barátné Hajdu Ágnes - Béres Judit (szerk.): Szövegértés-fejlesztés a könyvtárban. Bp.: Fővárosi Szabó Ervin Könyvtár, pp. 216-270.

Lassú Zsuzsa, F. (2009): Az irodalom visszavág - a fiúk olvasási és szövegértési nehézségeinek néhány lehetséges olvasata. In: Albert Gábor (szerk.): Az óvodapedagógiától az andragógiáig: Képzés és gyakorlat Konferencia III. Kaposvár: Kaposvári Egyetem, 464.

Rasmusson, Maria, - Aberg-Bengtsson, Lisbeth (2015): Does Performance in Digital Reading Relate to Computer Game Playing? A Study of Factor Structure and Gender Patterns in 15-Year-Olds' Reading Literacy Performance. Scandinavian Journal of Educational Research, 59(6), 691-709. DOI: 10.1080/00313831.2014.965795

Retelsdorf, Jan - Schwartz, Katja - Asbrock, Frank (2015): "Michael can't read!" Teachers' gender stereotypes and boys' reading self-concept. Journal of Educational Psychology, 107(1), 186-194. DOI: 10.1037/a0037107

Schleicher, Andreas (2019): PISA 2018 : Insights and Interpretations. (OECD 2019.) <URL: https://www.oecd.org/pisa/PISA\%202018\%20Insights\%20and\%20Interpre tations\%20FINAL\%20PDF.pdf [2019. 12. 20.]

Szinger Veronika (2009a): A nemek közötti különbségek megjelenése óvodáskorú gyermekek írásbeliséggel kapcsolatos tudásában és viselkedésében. In: Magyar Tudomány Ünnepe Bács-Kiskun Megyei Tudományos Fórum kötete. Kecskemét: Kecskeméti Főiskola, Szinger Veronika (2009b): Kisgyermekkori írás-olvasás esemény: Indirekt találkozás az írásbeliséggel iskoláskor elött. (doktori értekezés) Pécs: PTE BTK

Tóth Máté (2019): A 3-17 éves korosztály olvasási szokásai : Egy országos reprezentatív felmérés eredményei. In: Béres Judit (szerk.): A könyvtárhasználat és az információkeresés fejlesztése. (Módszertani kötetek 4.) Bp.: Fővárosi Szabó Ervin Könyvtár, pp. 261317.

Wolter, Ilka - Gluer, Michael, - Hannover, Bettina (2014): Gender-typicality of activity offerings and child-teacher relationship closeness in German "Kindergarten" : Influences on the development of spelling competence as an indicator of early basic literacy in boys and girls. Learning and Individual Differences, 31(Apr), 59-65.

DOI: $10.1016 /$ j.lindif.2013.12.008

\section{SUMMARY}

\section{Genders and answers: boys' reading incentive and performance in the face of} research results and good practices

Both national and international researches report that boys spend less time reading on average, they have lower reading incentive, they appreciate reading less, they consider themselves to be worse readers than girls, reading is rather considered to be a "girlish" pastime. The difference between girls and boys is continuously increasing with age, as it is confirmed by the results of the PIRLS and PISA tests. In the field of reading the biological approach of the differences between genders emphasizes those factors which are congenital ones or emerging as a consequence of maturity parallel to hormonal changes influencing cognitive abilities. Sociolinguistic aspects mention primarily those differences, which accidentally convey other patterns on behalf of the father and the mother during 
socialization. The study presents some pedagogical aspects as well, which help or unfortunately hinder boys to become readers, to shape their self-image as readers, their reading performance or their progress in kindergarten and school. The main aim of the study is to present those good practices, which primarily aim at boys. The Finnish project entitled "Reading fathers in kindergarten" starts from the facts that boys' interest in reading may mainly be raised by a male ideal, an adult man serving as a role model for them. The Boys \& Books website is primarily for those adults who may play any role in educating boys to become readers. The website offers boyish reading materials, methodological references for the teaching of reading. The German project entitled "The encounter of football with culture" which addresses particularly disadvantaged boys is based on the conviction that joining football, learning and culture motivates a lot of children and they become more receptive and interested in learning and reading. "The real men": the main conclusion of an American good practice is if we take into consideration what the boys would like to read, hear, talk about, then they can lose themselves in texts appealing to them. The PISA tests show clearly if boys become committed readers, they can perform better than girls. The good practices outlined in the study all contribute to the achievement of this goal.

Kulcsszavak: gender differences in reading, good practices, reading incentive 